International Journal of Instruction e-ISSN: 1308-1470 • www.e-iji.net

Article submission code: 20191013150951

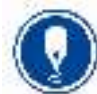

January $2021 \bullet$ Vol.14, No.1

p-ISSN: 1694-609X

pp. 283-302

Received: 13/10/2019

Revision: 20/06/2020
Accepted: 11/07/2020

OnlineFirst:18/10/2020

\title{
The Effect of the Implementation of Teaching Factory and Its Learning Involvement toward Work Readiness of Vocational School Graduates
}

\author{
Agus Prianto \\ Assoc. Prof., Economic Education Department of STKIP PGRI Jombang, East Java \\ Indonesia, agustkip@gmail.com \\ Winardi \\ Assoc. Prof., Civic Education Department of STKIP PGRI Jombang, East Java \\ Indonesia, win.stkipjb@gmail.com
}

\section{Umi Nur Qomariyah}

Mathematic Education Department of STKIP PGRI Jombang, East Java Indonesia, umi.stkipjb.gmail.com
The effectiveness of vocational schools (VS) can be assessed by the quantity of its graduates absorbed in the job market. Vocational schools that are assigned to produce graduates who have skills in accordance with the job market still face a great challenge. This is revealed from the open unemployment rate of VS' graduates who in the last few years always occupy the highest position. To overcome this problem, through Presidential Instruction 9 of 2016, the government decided to revitalize VS. As a follow-up to this policy, teaching factory (TF) based learning activities are implemented with the aim of providing knowledge, skills and learning experiences that are in line to the job market. This study examines the implementation of various TF-based learning models and their effects on student involvement in learning and strengthening work readiness. The unit of analysis in this study is the 2019 VS' graduates who have participated in TF-based learning. Descriptive analysis is used in this study to describe the intensity of graduates' involvement in TF-based learning when they were studying. Descriptive analysis is also used to describe the work readiness of the graduates. To analyze whether the various dimensions and indicators identified are the factors forming the involvement variables in TF learning and work readiness variables are analyzed using confirmatory factor analysis techniques.

Keywords: teaching factory, involvement, learning activities, work readiness, learning

\section{INTRODUCTION}

Vocational High School (VS) aims to prepare students to build readiness to work, have entrepreneurial spirit, smart, and competitive, in order to compete in the global market. Vocational education can be the mainstay of the economic improvement of countries in

Citation: Prianto, A., Winardi., \& Qomariyah, U. N. (2021). The Effect of the Implementation of Teaching Factory and Its Learning Involvement toward Work Readiness of Vocational School Graduates. International Journal of Instruction, 14(1), 283-302. https://doi.org/10.29333/iji.2021.14117a 
the long term and more futuristic improvement if the graduates' competence is directed to the needs of workforces and business development (Mulyati, et al., 2014).

The success of educational activities in vocational schools will be assessed by how many graduates can be absorbed in the workplace or be entrepreneur. Based on experiences from developed countries, such as in the European Union; Vocational and training education greatly contributes to prepare workforce with good skills (European Centre for the Development of Vocational Training [CEDEFOP], 2011).

In the Article 15 Act No 202003 on the National Education System specifically states that the purpose of secondary vocational education is to prepare students especially to be productive, to work independently, work in the business and industry field as a midlevel workforce related to the competence chosen in the vocational education. In addition, Clarke \& Winch (2007) stated that vocational education intends to develop employment, maintenance, acceleration, and increase the quality of workforce in order to improve the productivity of community. Thus, one of measurement used to measure the quality of vocational education activities is by examining the extent of students and graduate's readiness.

The effectiveness of vocational education can also be examined from the extent of graduates absorbed in the workplace or to be an entrepreneur. To be the best education, vocational high school is expected to prepare students to have the competence of work related to the demands of the industry or give a variety of knowledge and skills to be an entrepreneur.

Up to now, the expectation for vocational high school to produce graduates with good skills related to the demands of the workplace still face a big challenge. At least, this can be seen from the open unemployment rate of vacational graduates that always occupy the highest position in recent years. Based on Central Bureau of Statistics (CBS) data 2016, the number of unemployment as of February 2016 is 7 million people, with unemployent of vocational graduates at 9.84\% (Berita Resmi Statistik, 2016). Then the CBS data of August 2017 showed the unemployent of vocational graduates is at $11.41 \%$. While the CBS data of August 2018 showed the unemployent of vocational graduates is at $11.24 \%$ (Berita Resmi Statistik, 2018).

The statistical data seems to show that the existence of vocational high school has not yet fully met the expectation. The vocational graduates' qualifications of knowledge, competence and skill have not fully met with the demands of the workplace. In other words, there is a gap between the knowledge and competence of vocational graduates with the specification of skill demanded by the workplace. This raises the question of whether the learning activities carried out at Vocational Schools are fully adaptive and in line with workplace needs.

Hanafi (2012) states that there are several factors causing vocational school graduates are not absorbed, namely: (a) Industry commonly seeks workers experienced in their fields; (b) Industry always complains that vocational graduates have no good skills, easy to give up when the situations in workplace are changing. In addition, Sasmito, et al (2015) indicated that vocational graduates were not ready to enter the workplace 
because of their lack of work experience, and the readiness of graduates to work was considered low.

Based on the study of Hanafi (2012) and Sasmito et al (2015), the challenge for education in vocational schools is how to create learning activities providing knowledge, skills and learning experiences and these activities are in line with the demand in a business and an industry. Work experience can only be obtained if students are involved intensively in the internship program, or directly involved in activities on the business or industry. At the same time, the alignment of knowledge and skills learned by students with the business and industry will be more effectively realized if the business or industry are involved in the learning activities.

To prepare students to be ready to work and to be an enterpreneur after they graduate, it needs active learning, based on real activities, developing creativity and innovation; thus, the learning process can provide a strong learning experience (The EU, 2012). Active learning will encourage students to be more actively involved, responsible, full of initiative, have a deep involvement during learning activities, increase selfconfidence, and accustom students to think at a higher level (Ruskyte \& Navickas, 2017).

Teaching factory (TF) is a form of active learning, and it is implemented based on activities in business and industry to produce goods or services. It is implemented through synergy between schools and industries as partners and it is to strengthen students' competence. The main purpose of implementing $\mathrm{TF}$ is to eliminate the competency gap between what is expected by the industry and what students learn in school. In addition, TF-based learning can also be a productive activity that generates benefits for schools, teachers, or students, and activates economic activities at the local level (Damarjati, 2017).

TF-based learning began to be implemented intensively in various vocational schools that participated in the revitalization program, along with the issuance of Presidential Instruction No. 9 of 2016 concerning vocational school revitalization. State Vocational high School 1 Jombang, State Vocational high School 1 Magetan, State Vocational high School 1 Malang, and Vocational high School PGRI 1 Giri Banyuwangi are some of the Vocational Schools that participated in the first revitalization program, and have been implementing TF-based learning since then. In 2019 these schools have graduated students who have followed TF-based learning throughout their study process. Thus it can be stated that the graduates of these schools are the first graduates who have been taught with The TF-based learning approach.

This study intends to examine the extent of the effect of the implementation of TF-based learning towards work readiness of vocational schools' graduates who have participated in revitalization programs. There are 5 sub-models of TF-based learning that have been implemented in vocational schools, namely: (1) internships (Itshp), (2) production-based education and training (Pbet), (3) cooperative education placement (Cep), (4) schoolbased enterprise (Sbe), and (5) service learning (Sl). 
This study will analyze how the effect of the implementation of the 5 TF-based learning sub-models on the work readiness of students and graduates. This study will also examine the intensity of students' involvement while participating in TF-based learning that is assumed to influence the work readiness. Furthermore, this study will also analyze from the 5 TF-based learning sub-models, which have the strongest effect on work readiness of the graduates. It is expected from this study that TF-based learning sub-models can be identified as an effective model in strengthening work readiness for students and graduates.

\section{Literature Review}

TF is a learning concept based on production or service activities that refer to standards and procedures that apply in the industry, and its activities are conducted in an atmosphere within the industry. The concept of TF is a form of developing vocational schools into a model of production schools (Siswanto, 2015). Thus TF-based learning will be implemented more with practical activities.

According to Triatmoko (2009), the TF-based learning models was first implemented because vocational high schools was experiencing difficulties in implementing production-based education and training activities. To overcome the difficulties of carrying out production-based education and training activities, the vocational high school established a production unit and business center as a place of learning for students to carry out the practice of producing goods and services that have a sale value.

In developed countries, the synergy between the industrial world and vocational schools has run very well. Vocational schools in Germany, for example, theoretical learning is taught in schools for two days per week, while practical activities are implemented in industry (Moerwismadhi, 2009). By implementing TF, it is expected to be able to overcome the competence gap, between the competencies expected by the business and the industry with the competence developed by schools. Thus, in implementing TF activities the school must involve the business and the industry to be involved in evaluating the achievement of students' competence.

Involving business and industry in learning activities, the school will be able to follow the development of technology and business activity management. Through this implementation, schools will more quickly update curriculum, competence and subjects, and the implementation of learning activities will be in line with market demands. The basic principle of $\mathrm{TF}$ is factory to classroom, it aims to transfer the actual production environment in the industry into the practice room at school. The situation that occurs in real production activities is needed to improve the competence of real-based teaching from daily industrial practices (Khurniawan et al, 2016).

TF-based learning activities will provide benefits to both schools and industries. For schools, TF will provide an opportunity for schools to modernize their learning activities that are always in line with the development of business and industrial activities. For business and industry, the implementation of $\mathrm{TF}$ will be able to improve the performance through the availability of new workers who have the latest skills as expected by the industry. 
The TF-based learning approach that is commonly implemented in vocational schools is work based learning (Ferrandez Berrueco et al, 2016), it is learning activities designed to involve students in business activities and learning activities at school at one time. In a number of vocational schools participating in the revitalization program, students will be placed in business and industry after learning theory in schools through internship program (McHug, 2017), production-based education and training (Mulyatiningsih et al, 2014 ), cooperative education placement (Howard, 2004), school-based enterprise (Arenas, 2003) and service learning (Kasinath, 2013).

Internship is a work-based learning approach that provides opportunities for students to work in industry for a specified period of time (Cooper, et al, 2009; McHug, 2017). In some vocational schools, this activity is well-known as industrial work practice. Through internship activities, students are expected to be able to apply the competencies they have learned at school to be practiced in the business and industry. In other words, students who have finished participating in the internship program should have early preparation to work according to their field of competence.

Production-based education and training is a process of education and training that is implemented with production activities, so students will gain learning experiences in real situations as in the industry (Mulyatiningsih, et al, 2014). The activity begins with planning, this activity includes ordering goods and services, the production process of goods and services, evaluation of goods and services produced, up to various service activities to customers who has ordered goods and services. Through production-based education and training activities, students will gain work experience and experience running business activities.

Cooperative education placement is usually done by positioning the school as a place to develop human resources, while the industry provides the resources and instructors needed for these activities (Howard, 2004). This program provides benefits for both the school and industry. Schools will receive support for resources to develop student competencies to be in line with industry needs. The teachers will also get knowledge and information related to competencies that must be taught to students. Conversely, the industry will also get support for the availability of workers in accordance with the specification of the skills they want. Thus, the work placement activity will make students have early readiness to work in accordance with their field of competence.

School-based enterprise is implemented in the form of work practices in production units or business units in schools (Cooper et al, 2004; Haase \& Lautenschlager, 2011; Arenas, 2003). Students are taught to organize business activities in schools under the supervision of teachers, ranging from product or service planning, production activities, structuring, promotion, sales, customer service, up to evaluation after these series of activities are conducted. In some vocational schools that have business units, such as shops, production workshops, hotels and others, they will be able to provide students with learning experiences on how to manage business activities, from planning to selling products or services. Thus, the involvement of students in work practice activities in business units plays a role in strengthening work readiness and fostering interest in the field of entrepreneurship. 
Service learning provides opportunities for students to organize activities that are directed to serve the community, participate in overcoming various problems faced by citizens, both in the provision of products and services (Kasinath, 2013). Students are trained to identify various life problems experienced by community members according to their area of expertise. Based on the results of identification, students, under the guidance of the teacher, design activities, create products or services to be offered to citizens. Thus, the involvement of students in Service learning activities plays a role in strengthening work readiness and fostering interest in the field of entrepreneurship.

Various studies have been conducted to identify various indicators used to examine work readiness. Brady (2010) has reviewed several personality attributes that are used to examnine the level of readiness to work. This study was later expanded and deepened by Caballero, et al (2011). Referring to the study conducted by Brady (2010), there are 6 individual indicators of readiness to work. they are (a) responsible attitude, (b) ability to think and act flexibly, (c) having a variety of life skills, (d) communication skills both verbally and written, (e) ability to perform self-evaluation, and (f) awareness of their own health and safety.

Responsible attitude will be shown from the behavior of workers to arrive at work on time and will continue to work untill the time to stop related to the schedule of work time. They have a high concern with a variety of tools and equipment used for work, have a quality of work standards, and understand the advantages and disadvantages of various work behaviors. They have full awareness that success and career in the workplace will be influenced by their own work performance (Reynolds \& Ceranic, 2007). Responsible workers are always characterized by personal integrity, honesty and trustworthiness (Gardner, et al. 2001).

The study by Gardner, et al. (2001) state that more than two-thirds of employees considered that responsible attitude in the workplace is a very important personality attribute. This is not only a responsible attitude for self-interest, but also a responsible attitude towards partners and the organization. Finally, this responsible attitude is also devoted to the progress of the organization where they work (Gardner, 2007). Therefore, Parker (2008) states that responsible attitude is one of the main personality attributes that must be possessed by workers and prospective workers in the 21 st century.

The ability to think and act flexibly is shown by the ability of workers to continue to adapt various changes that occur in the workplace (Moorhouse \& Caltabiano, 2007). They realize that new trends will come very quickly. This situation requires the ability to quickly adapt to work patterns and new work skills in accordance with the demands that are developing in the community. In a rapidly changing world, the ability to adapt to the demands of new skills and expertise is part of the life skills that must be possessed by workers and prospective workers in the 21 st century.

Parker (2008) revealed that self-encouragement to keep self learning related to the demands of workforce is an important part of work skills. Someone who has ability to teach themselves will encourage them to keep trying to master a variety of new knowledge and skills. Their involvement in various education and training programs is 
truly realized as part of the needs, and not because of demands or pressure from the organization (Brady, 2010). Thus someone who has the need to keep updating knowledge, skills and expertise will have more readiness to work.

Good communication skills from someone, both orally and written, is a part of work skills that will strongly support the creation of a conducive work atmosphere. Various work problems often occur because of communication problems, both communication between partners of workers, communication with organizations, and communication with the community. Thus it can be said that communication skills are factors that determine work readiness (Caballero, et al, 2011; Porath \&; Porath \& Bateman, 2006; Brady,2010).

Individuals' readiness to work can also be identified from their ability to conduct selfevaluation. This is shown by the ability of someone to realize how they place themselves in the life of the organization where they work, so they understand what must be done to improve their performance. The ability of self-evaluation makes someone easy to receive feedback, encourage them to keep learning, and explore their knowledge about an impact on self-confidence. Someone with strong self confidence is proven to have good performance (Betz, 2004). Thus a person's ability to conduct self-evaluation also reflects personal maturity, and this affects the work readiness (Caballero, et al. 2011).

Wagner (2006) has explained that there are 14 factors that make a person considered more ready to work. The 14 factors include: suitability of expertise and skills with the demands of workplace, academic achievement, strong personality attitude, confidence, strong motivation, encouragement and enthusiasm at work, strong leadership, Readiness for a presentation interview, prioritizing long-term advantage, realistic wage demands, personal maturity, intensive involvement in extra-curricular activities during study, adequate basic skills, and mental readiness to work.

Brady (2010), Caballero et al. (2011), and Prianto (2013) have identified various attributes expected of job providers and they must be owned by job seekers, as shown in table 1. Thus, someone who has these attributes is assumed to have high work readiness.

Table 1

Various attributes expected by employers

\begin{tabular}{lll}
\hline Number & Factor & Attribute \\
\hline 1 & Motivation & $\begin{array}{l}\text { Working hard, drive to work hard, persistence, consistent, work } \\
\text { best, never give up, not easy to complain. }\end{array}$ \\
\hline 3 & $\begin{array}{l}\text { Personal } \\
\text { Maturity }\end{array}$ & $\begin{array}{l}\text { Stand to problems, calm to criticsm, open minded, confident, } \\
\text { responsible. }\end{array}$ \\
\hline 4 & $\begin{array}{l}\text { Social } \\
\text { maturity }\end{array}$ & $\begin{array}{l}\text { Well-communication, colaboration, building relationships, interact } \\
\text { with customers, flexible. }\end{array}$ \\
\hline 5 & $\begin{array}{l}\text { Attitudes to } \\
\text { work }\end{array}$ & $\begin{array}{l}\text { Respectful attitude, Careful, Responsive, Realistic and simple, } \\
\text { polite, humble, patient. }\end{array}$ \\
& $\begin{array}{l}\text { Work } \\
\text { competence }\end{array}$ & $\begin{array}{l}\text { Having knowledge and skills related to the field of work, analyzing } \\
\text { the problem, self-evaluation related to the field of work, looking for } \\
\text { new ways of working more effectively and efficiently, Dare to } \\
\text { make decisions, Quickly adopt new ways of working. }\end{array}$ \\
\hline
\end{tabular}




\section{METHOD}

This research uses a quantitative research approach. Data on the involvement of graduates in TF-based learning in their study and work readiness was measured by using a likert model questionnaire on a 5 scale. The questionnaire was developed based on various indicators from students' involvement in TF-based learning and work readiness. Through the questionnaire, the graduates were also asked to choose one of the five TF based learning models, proposed in this study, which the graduates considered to provide valuable experience in preparing themselves to enter the workforce. Five TFbased learning models, namely: (1) internship, (2) production-based education and training, (3) cooperative education placement, (4) school-based enterprise, and (5) service learning. Then, graduates are asked about their involvement in learning when they were studying.

The indicators of students' involvement in TF-based learning are: (1) intensity of participation in learning activities ( $\mathrm{PrCt}$ ), (2) attention (Attn), (3) teamwork (TWk), (4) initiative (Int), (5) commitment to complete tasks (Cmtn), (6) encouragement to be the best (E-Tb), (7) responsible for assigned tasks (Rnsbt), (8) proud of the work (PRoW), (9) encouragement to have high order thinking while doing the tasks (HOTs), (10) communication among team work members $(\mathrm{Cmnc})$.

The Indicators of work readiness are: (1) motivation (Motiv), there are 7 sub-indicators (Working hard, drive to work hard, persistence, consistent, work best, never give up, and not easy to complain.); (2) personal maturity (Persn-Mat), there are 5 sub-indicators (Stand to problems, calm to criticism, open minded, confident, and responsible); (3) social maturity (Soc-Mat), there are 5 sub-indicators (Well-communication, collaboration, building relationships, interact with customers, and flexible.); (4) Work Attitudes (Wrk-Att), there are 7 sub-indicators (Respectful attitude, Careful, Responsive, Realistic and simple, polite, humble, and patient.); and (5) work competence (Wrk-Cmpt), there are 6 sub-indicators (Having knowledge and skills related to the field of work, analyzing the problem, self-evaluation related to the field of work, looking for new ways of working more effectively and efficiently, Dare to make decisions, Quickly adopt new ways of working).

The research questionnaire was developed based on various indicators extracted from various theoretical studies and the result of previous studies. There are 10 questionnaire items with the best coefficient of validity for students' involvement in TF-based learning. While the work readiness questionnaires were derived from each indicator and sub-indicator. There are 30 questionnaire items with the best coefficient of validity for work readiness.

The population in this study were 1412 graduates in 2019 from State Vocational High School 1 Jombang, State Vocational High School 1 Malang, State Vocational High School 1 Magetan, and State Vocational High School PGRI 1 Giri Banyuwangi. The selection of 2019 graduates as a unit of analysis is based on the consideration that all of them have been involved in TF-based learning. As new graduates, they are expected to be able to express their opinions on the learning activities they have participated before. 
The research sample was determined using the formula of proportional random sampling technique with a margin of error of 5\% to get a sample of 311 graduates (Scheaffer, et al (2012). To get sample from the 4 schools, this research used. Then, 311 samples given the questionnaire, there were 163 graduates who completed the questionnaire and submitted it to researchers, or $52 \%$ of the total sample.

Descriptive analysis is used in this study to describe the intensity of graduates' involvement in TF-based learning when they were studying. Descriptive analysis is also used to describe the work readiness of the graduates. The score of the intensity of graduates' involvement in learning and work readiness were developed by taking into account the range of questionnaire answer scores (5-1) divided by the number of scores used by 5 categories, so that the length of the interval class was obtained in 5 scorecategories, as shown in table 2.

Table 2

Involvement in learning and work readiness scores

\begin{tabular}{lllll}
\hline No & Interval Class & Score & Intensity of Involvement & Work Readiness \\
\hline 1 & $1.00-1.8$ & $20.0-36$ & Very low & Very Not Ready \\
\hline 2 & $1.81-2.6$ & $36.1-52$ & Low & Not ready \\
\hline 3 & $2.61-3.4$ & $52.1-68$ & Moderate & Ready enough \\
\hline 4 & $3.41-4.2$ & $68.1-84$ & High & Ready \\
\hline 5 & $4,21-5.00$ & $84.1-100$ & Very high & Very ready \\
\hline
\end{tabular}

To analyze whether the various dimensions and indicators identified are the factors forming the involvement variables in TF learning and work readiness variables are analyzed using confirmatory factor analysis techniques. The confirmatory factor analysis technique intends to confirm whether the measurement model developed meets the hypothesis. Thus the confirmatory factor analysis will examine whether the model developed is really fit. The various parameters used to test the fit model include: (a). $\chi^{2}$ Test. The model is good if the $\chi^{2}$ test is not real at any particular level. (b). GFI (Goodness of Fit Index). A general rule suggested for the feasibility of a model is that the GFI value is more than 0.90 and the maximum value is 1. (c). AGFI (Adjusted Goodness of Fit Index). A model is said to be good if the AGFI value is more than 0.80 and the maximum value is 1. (d). RMSEA (Root Mean Square of Error Approximation). If the RMSEA $\leq 0.08$, in general the model already represents the actual data (Ferdinand, 2002). To support the analysis, the research used LISREL 8.30 for windows software.

The model that is really fit reflects the existence of a truly valid indicator. This is done by conducting a construct unidimensionality test to ensure that the dimensions of the variables and indicators identified are elements of each latent variable intact. In other words, various indicators as shown in the fit model are as a manifestations of work readiness. To analyze the fit model is done by comparing the p-value coefficient ( $p$ ) with the alpha coefficient $(\alpha)$ that is set at 0.05 . If the alpha coefficient $(\alpha)$ is smaller than the $\mathrm{p}$-value, or $\mathrm{p}>\alpha$, then the integrity of the model illustrated by the relationship between manifest variable with the latent variables is acceptable (Ferdinand, 2002). 
This study will also analyze the effect of implementation of TF-based learning models and graduates' involvement in learning on the work readiness. For this reason, univariate analysis with SPSS for windows software will be used.

\section{RESULTS AND DISCUSSION}

\section{The Implementation of TF-Based Learning}

This study revealed 5 TF-based learning models perceived by graduates to provide indepth experience and play a major role in forming work readiness, as shown in table 3.

Table 3

TF-Based learning model of graduate's choices

\begin{tabular}{llll}
\hline Learning Model & Respondents & Percentage & Description \\
\hline Internship & 75 & 46 & $\begin{array}{l}\text { It is well-known as "Internship (Prakerin)" } \\
\text { for graduates }\end{array}$ \\
\hline $\begin{array}{l}\text { Production-based } \\
\text { education and training }\end{array}$ & 35 & 21,5 & Making products and marketing \\
\hline $\begin{array}{l}\text { Cooperative education } \\
\text { placement }\end{array}$ & 9 & 5,5 & $\begin{array}{l}\text { Placement in the business and industry in } \\
\text { collaboration with schools }\end{array}$ \\
\hline School-based enterprise & 34 & 20,9 & Work practices in business units at schools \\
\hline Service learning & 10 & 6,1 & $\begin{array}{l}\text { The learning program is developed based } \\
\text { on problems in the community }\end{array}$ \\
\hline Total & 163 & 100 & \\
\hline
\end{tabular}

Source: Data processed by the researchers

This research successfully revealed that there were 3 main TF-based learning models chosen by graduates, and were perceived to provide deep experience and play a major role in forming work readiness, namely: (1) internship (46\%), (b) production-based education and training, in the form of product manufacturing activities up to product marketing (21.5\%), and (3) school-based enterprise (20.9\%). Two other learning models, cooperative education placement $(5.5 \%)$ and service learning $(6.1 \%)$, seem unfamiliar to most graduates. This is possible because these two learning models have not been developed much in schools.

The involvement of respondents in learning activities can be explained in table 4 .

Table 4

Respondents proportion average in TF learning

\begin{tabular}{lllll}
\hline Learning model & $\begin{array}{l}\text { Average of } \\
\text { Involvement }\end{array}$ & $\begin{array}{l}\text { Min. } \\
\text { Score }\end{array}$ & $\begin{array}{l}\text { Max. } \\
\text { Score }\end{array}$ & $\begin{array}{l}\text { Quality of } \\
\text { involve }\end{array}$ \\
\hline Internship & 83.9 & 68 & 100 & High \\
\hline $\begin{array}{l}\text { Production-based education and } \\
\text { training }\end{array}$ & 87.8 & 70 & 100 & Very high \\
\hline Cooperative education placement & 85.9 & 76 & 100 & Very high \\
\hline School-based enterprise & 83.7 & 66 & 100 & High \\
\hline Service learning & 86.1 & 80 & 100 & Very high \\
\hline
\end{tabular}

Source: The data was analyzed by the researchers 
The details of the respondents' involvement in learning activities in accordance with the TF-based learning model that is perceived to be the most dominant form of work readiness are shown in Figure 1. The involvement in learning is explained in 10 indicators including: (1) participation ( $\mathrm{PrCt},(2)$ attention (Attn), (3) teamwork (TWk), (4) initiative (Int), (5) commitment (Cmtn), (6) encouragement to be the best (E-Tb), (7) responsible (Rnsbt), (8) proud of the results of the work (PRoW), (9) using high-order thinking skills, optimal thinking (HOTs), and (10) communication skills (Cmnc).

Figure 1 shows that the five TF-based learning models are able to foster aspects of participation, attention, commitment to the task, and communication skills that are relatively similiar, with a range of scores between 84-88 (Involvement in learning is very high).

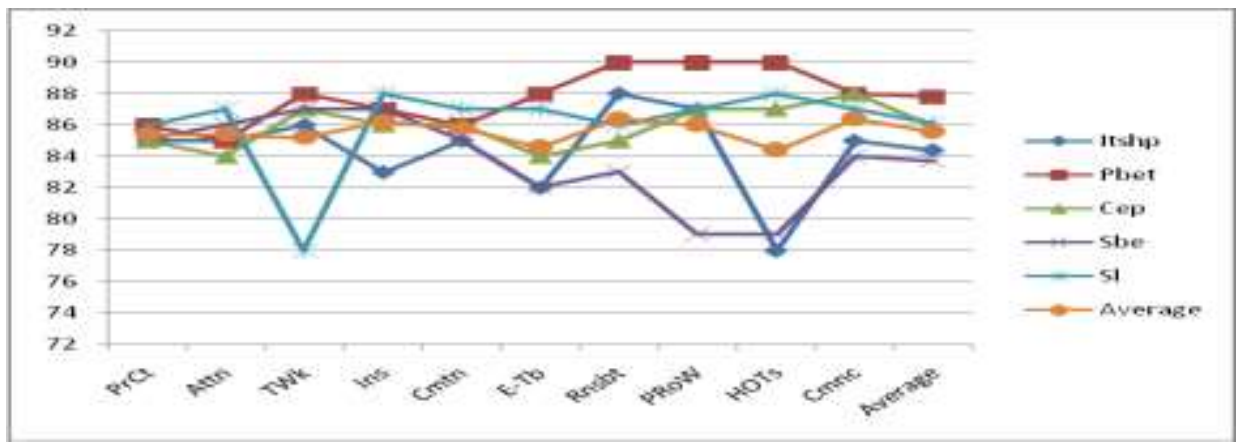

Figure 1

Indicators of student's involvement related to the learning model

Differences with involvement in learning are identified for several indicators, as follows:

1. Teamwork. The process of community service-based learning produces involvement in learning in the "high" category with the score of 78. It happenned because the learning activities are carried out more individually. While the four other learning models resulted learning involvement in the "very high" category with the score ranges from 86 - 88. In other words, internship activities, work practices in business units, production-based learning, and cooperative education placement are perceived to play a very large role to build skills of working together.

2. Initiative Power. This study revealed that internship activities have not been able to generate optimal initiative power, with the involvement score of 83 ("high"), while the other four learning models resulted learning involvement in the "very high" category with the involvement score ranging from 86 - 88. In other words, service learning, work practices in business units, production-based education and training, and cooperative education placement are perceived to play a very large role in building initiative power.

3. The drive to be the best. This study revealed that apprenticeship activities and work practices in business units have not been able to generate encouragement to be the best optimally, with the involvement score of 82 ("high"), while three other learning 
models resulted learning involvement in the "very high" category with the involvement score ranging from 84-88. In other words, service learning, productionbased education and training, and cooperative education placement activities are perceived to play a huge role in fostering the drive to be the best.

4. Responsibility. This study revealed that work practice activities in business units have not been able to optimize the attitude of responsibility, with the involvement score of 83 ("high"), while the other four learning models resulted learning involvement in the "very high" category with the involvement score ranging from 84-88. In other words, internship, service learning, production-based education and training, and cooperative education placement are perceived to play a very large role in strengthening optimal attitude of responsibility.

5. Proud of the work. This study revealed that work practice activities in business units have not been able to arouse feelings of pride towards the optimal work results, with the involvement score of 79 ("high"), while the other four learning models resulted learning involvement in the "very high" category with the involvement score ranging from 87 - 90. Production based learning can produce feelings of pride with the highest score of 90 ("very high"). In other words, internship, service learning, production-based education and training, and cooperative education placement are perceived to play a very large role in fostering feelings of pride in the results of their work.

6. High order thinking skill, optimal thinking, includes critical thinking skills, creative, innovative, ability to solve problems, analyze, synthesis, and evaluative thinking. This study revealed that internship activities and production-based education and training have not encouraged respondents to use high-order thinking skills optimally, with the involvement scores between 78 to 79 ("high"), while the other three learning models resulted learning involvement in the "very high "with the involvement scores ranging from 87 to 90 . Production based learning can produce feelings of pride with the highest score of 90 ("very high "). In other words, service learning, productionbased education and training, and cooperative education placement are perceived to play a huge role in strengthening thinking skills at a high level.

This research has identified 3 TF-based learning models that are considered the most capable to build students' involvement in learning activities, they are: production based learning, service learning, and cooperative education placement. Although only a small portion of graduates are revealed, the service-learning model and cooperative education placement are perceived very well by graduates. This information can certainly be considered by schools to develop learning activities in schools. Production-based learning is perceived by respondents as the most powerful in building involvement in learning activities.

\section{Work Readiness}

Descriptive analysis results of work readiness in accordance with the learning model that is perceived to provide in-depth experience by respondents is seen in table 5 . 
Table 5

Means of work readiness based on the selected learning model

\begin{tabular}{lllll}
\hline \multirow{2}{*}{ Learning Model } & $\begin{array}{l}\text { Means of } \\
\text { readiness }\end{array}$ & $\begin{array}{l}\text { Lowest } \\
\text { Score }\end{array}$ & $\begin{array}{l}\text { Highest } \\
\text { Score }\end{array}$ & $\begin{array}{l}\text { Quality of } \\
\text { readiness }\end{array}$ \\
\hline Internship & 74.6 & 64 & 86 & Ready \\
\hline Production-based education and training & 78.4 & 70 & 86 & Ready \\
\hline Cooperative education placement & 83.8 & 76 & 88 & Ready \\
\hline School-based enterprise & 78.6 & 66 & 84 & Ready \\
\hline Service learning & 81.4 & 80 & 88 & Ready \\
\hline
\end{tabular}

Source: The data was analyzed by researchers

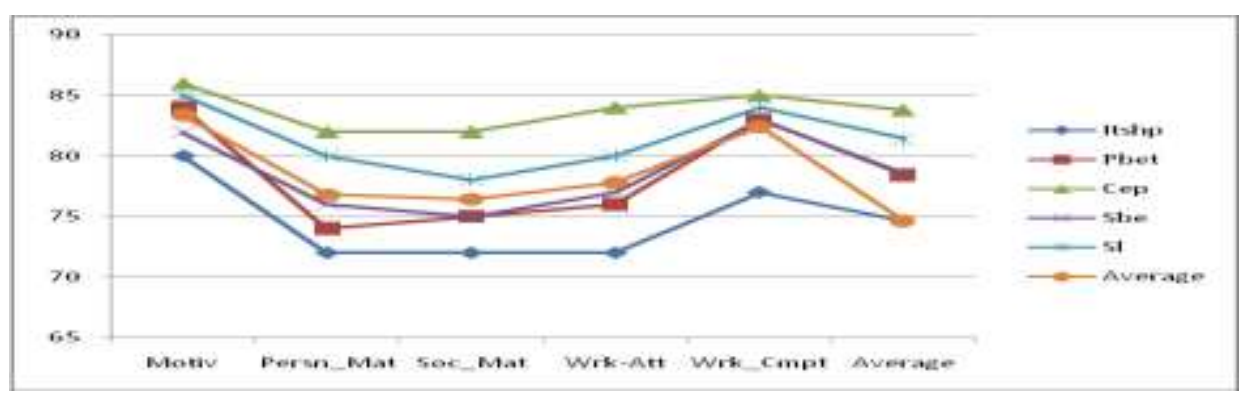

Figure 2

TF-based learning models

Based on Figure 2, it was revealed that overall the five TF-based learning models implemented by schools were able to shape graduates' work readiness in the "ready" category. Seeing each indicator, the five TF-based learning models have relatively similar effects on indicators of motivation and work skills. The application of cooperative education placement model provides the greatest contribution to work readiness, as well as the service learning model, school-based enterprise, productionbased education and training, and the internship program.

Although they have relatively equal effects on the indicators of motivation and work skills, the five learning models seem to have different effects on the indicators of personal maturity, social maturity, and attitude to work. Figure 2 shows that there are 3 categories of learning models that have different effects.

Seeing the indicators of personal maturity, social maturity, and attitude to work, cooperative education placement activities and community service based learning are the first category that respondents perceive to have the strongest effect on work readiness. Then followed by work school-based enterprise and production-based education and training as the second category, and the last category is the internship program.

Based on the empirical data above, the school needs to evaluate the implementation of internship activities. The large number of students who take the internship can have an effect on the choice of internship place by students who may not be equal with the main competency they have. There are equal internship activities with main competency, for 
example: students study about hotel and they do internships in hotels, or students study building technique and they do internship in real estate companies. To strengthen the linearity of internship activities, it is necessary to strengthen the synergy between the school and the business institution, especially related to the technical issues in the implementation of the internship activities in order to focus on the students' competency applied in the internship.

To find out whether the five TF-based learning models have significantly different effect on work readiness can be seen from the results of the statistical tests as listed in table 6 and table 7 .

Table 6

The Difference effect between the implementation of learning models towards work readiness

\begin{tabular}{llllll}
\hline Source & Type III Sum of Squares & Df & Mean Square & F & Sig. \\
\hline Corrected Model & $6.778^{\mathrm{a}}$ & 4 & 1.694 & 7.219 & .000 \\
\hline \multicolumn{1}{l}{ Model } & 1310.010 & 1 & 1310.010 & $5.581 \mathrm{E} 3$ & .000 \\
\hline Error & 6.778 & 4 & 1.694 & 7.219 & .000 \\
\hline Total & 37.087 & 158 & .235 & & \\
\hline Corrected Total & 2282.000 & 163 & & & \\
\hline a. R Squared = .155 (Adjusted R Squared =.133) & 162 & & & \\
\hline Computed using alpha $=.05$ &
\end{tabular}

The results of the statistical test prove that the five TF-based learning models applied in schools provide a significant difference in effect on work readiness. TF-based learning models that have a dominant influence in shaping the work readiness of graduates as described in the description above.

Table 7

Multiple comparisons among various learning models

\begin{tabular}{|c|c|c|c|c|c|c|}
\hline \multirow{2}{*}{$\begin{array}{l}\text { (I) Learning } \\
\text { Model }\end{array}$} & \multirow{2}{*}{$\begin{array}{l}\text { (J) Learning } \\
\text { Model. }\end{array}$} & \multirow{2}{*}{ Mean Diff. (I-J) } & \multirow{2}{*}{ Std. Error } & \multirow{2}{*}{ Sig. } & \multicolumn{2}{|c|}{$\begin{array}{l}95 \% \text { Confidence } \\
\text { Interval }\end{array}$} \\
\hline & & & & & $\begin{array}{l}\text { Lower } \\
\text { Bound }\end{array}$ & $\begin{array}{l}\text { Upper } \\
\text { Bound }\end{array}$ \\
\hline \multirow{4}{*}{ Internship (Itshp) } & Production (Pbet) & $-.2629^{*}$ & .08830 & .003 & -.4373 & -.0885 \\
\hline & Placement (Cep) & $-.5422^{*}$ & .15216 & .000 & -.8428 & -.2417 \\
\hline & Practice (Sbe) & $-.2318^{*}$ & .08918 & .010 & -.4079 & -.0556 \\
\hline & Service $(\mathrm{Sl})$ & $-.4200^{*}$ & .14521 & .004 & -.7068 & -.1332 \\
\hline
\end{tabular}

Based on observed means.

*. The mean difference is significant at the .05 level.

The results of the statistical test prove that the involvement of respondents in internship (Itshp) has a significant effect difference with school-based enterprise (Sbe), productionbased education and training (Pbet), service learning (Sl), and cooperative education 
placement in the business institution (Cep). The results of this study revealed various learning models that most strongly to the most weakly influence to the work readiness, as follows: (1) cooperative education placement in the business and industry, (2) service learning, (3) production-based education and training, (4) school-based enterprise, and (5) internship.

The results of the confirmatory factor analysis to determine the various manifest variables in constructing the work readiness were conducted 3 times examination for determine the fit model. The validity of each manifest variable for the construct of work readiness is presented in table 8 .

Table 8

The validity of the construct of work readiness

\begin{tabular}{llllll}
\hline No & Manifest Variable & $\lambda$ & $\mathrm{R}^{2}$ & T-Value & Conclusion \\
\hline 1 & Motivation & 0.74 & 0.55 & 9.30 & Valid \\
\hline 2 & Personal maturity & 0.82 & 0.68 & 10.78 & Valid \\
\hline 3 & Social maturity & 0.85 & 0.72 & 9.68 & Valid \\
\hline 4 & Attitude to Work & 0.81 & 0.66 & 10.45 & Valid \\
\hline 5 & Work competence & 0.80 & 0.64 & 10.29 & Valid \\
\hline
\end{tabular}

Source: Data was analyzed by researchers

The construct reliability of work readiness is measured using a formula developed by Bagozzi in Hasan (1995) by taking into account, the coefficient of loading factor and error. The results of the calculation of construct reliability obtained reliability coefficient of 0.82 (reliable). There is also the result of testing the alignment and integrity of the work readiness construct model shown in table 9.

Based on the results of the model fit test, it can be stated that the construct of work readiness has fulfilled the stipulated conditions, so that it can be said to be a complete construct. In other words, the respondent's work readiness in this study can be manifested from the variables of motivation, personal maturity, social maturity, work attitude, and work competence.

Table 9

The result of the fit test of construct model on work readiness

\begin{tabular}{llll}
\hline Fit Model & Coefficient & Criteria & Conclusions \\
\hline Chi-Square $\left(\chi^{2}\right)$ & 6,34 & Low $($ not significant) & Good, fulfilled \\
\hline P-value & 0,71 & $>0.05$ & Good, fulfilled \\
\hline Df & 6 & -- & \\
\hline Cmin $\left(\chi^{2} /\right.$ Df $)$ & 1.056667 & $<2.00$ & Good, fulfilled \\
\hline RMR (standardized) & 0.025 & $<0.08$ & Good, fulfilled \\
\hline RMSEA & 0.000 & $<0.08$ & Good, fulfilled \\
\hline GFI & 0.96 & $>0.90$ & Good, fulfilled \\
\hline AGFI & 0.94 & $>0.90$ & Good, fulfilled \\
\hline CFI & 1.00 & $>0.94$ & Perfect \\
\hline IFI & 1.01 & $>0.94$ & Perfect \\
\hline NNFI & 1.01 & $>0.94$ & Perfect \\
\hline
\end{tabular}

Source: The data was analyzed by researchers 
This study also revealed various indicators of manifest variables as the construct of work readiness as described in table 10.

Table 10

Various indicators forming the manifest variable of the construct work readiness

\begin{tabular}{|c|c|c|}
\hline $\begin{array}{l}\text { Latent } \\
\text { Variable }\end{array}$ & $\begin{array}{l}\text { Manifest } \\
\text { Variable }\end{array}$ & Variable Indicator Revealed \\
\hline \multirow{21}{*}{$\begin{array}{l}\text { Work } \\
\text { Readiness }\end{array}$} & \multirow{5}{*}{ Motivation } & Seriously running a job \\
\hline & & Willingness to work hard \\
\hline & & Resilience or persistence \\
\hline & & Not easy to give up when faced with difficulties \\
\hline & & Carrying out work with a happy attitude \\
\hline & \multirow{4}{*}{$\begin{array}{l}\text { Personal } \\
\text { maturity }\end{array}$} & Accept criticism with an objective attitude \\
\hline & & Be open to ideas or new ideas and be judged better \\
\hline & & Believe in your own abilities \\
\hline & & Accept responsibility and maintain the trust given by other parties \\
\hline & \multirow{3}{*}{$\begin{array}{l}\text { Social } \\
\text { maturity }\end{array}$} & Able to communicate well \\
\hline & & Able to work together in teamwork \\
\hline & & Be flexible in carrying out work \\
\hline & \multirow{5}{*}{$\begin{array}{l}\text { Work } \\
\text { attitude }\end{array}$} & Show sincere respect for others \\
\hline & & $\begin{array}{l}\text { Responsiveness to the situation around him, especially with regard } \\
\text { to his work }\end{array}$ \\
\hline & & Careful in carrying out the work \\
\hline & & Realistic, simple \\
\hline & & Maintain an attitude of courtesy to all parties \\
\hline & \multirow{4}{*}{$\begin{array}{l}\text { Work } \\
\text { competence }\end{array}$} & Having knowledge and skills in accordance with their work \\
\hline & & Able to make a problem analysis at work \\
\hline & & $\begin{array}{l}\text { Have a strong drive to adopt new ways of working which are } \\
\text { considered more effective and efficient }\end{array}$ \\
\hline & & Dare to make decisions in accordance with the field of work \\
\hline
\end{tabular}

\section{CONCLUSION}

There are five TF-based learning models implemented in Vocational Schools, they are internship, production-based education and training, school-based enterprise, cooperative education placement in business and industry, and service learning. The five TF-based learning models are perceived by respondents to have a very strong effect in terms of learning involvement, especially in terms of indicators of participation, attention, commitment, communication.

Except for service-based learning, TF-based learning models are also perceived to be able to foster the ability to work together in teams. Internship activities and school-based enterprise have not been able to foster the drive to be the best and high order thinking. This is because when participating in internship and work practices, more respondents are waiting and following orders from the manager in the internship place. It is assumed that the manager of the internship still considered respondents are at the learning stage so that the greater trust cannot be given in carrying out their duties at the internship. 
From the five learning models, production-based learning activities are perceived that the respondents are most able to build their involvement in learning activities.

The TF-based learning model which is perceived to be the most powerful in building involvement in learning, as follows: (1) cooperative education placement, (2) service learning, (3) school-based enterprise, (4) production-based education and training, and (5) internship. The last three learning models are the most widely implemented learning models in schools. Specifically, for the internship, it was perceived by respondents that they had not provided a very strong provision in shaping work readiness. This is partly due to the choice of internships by students who are not fully equal with their competencies.

Although production-based learning is able to build the strongest involvement in learning, it turns out that the learning model is perceived that it does not provide the most optimal effect in building work readiness. Production-based learning is more relevant for the purpose of building capabilities in developing independent businesses.

The TF-Based Learning models that are perceived to be the most influence on the formation of work readiness, as follows: (1) ) cooperative education placement, (2) service learning, (3) production-based education and training, (4) school-based enterprise, and (5) internship.

\section{SUGGESTIONS}

There are two learning models, that are service learning and cooperative education placement were revealed by a small of respondents. This raises the question for the next research, have schools not intensively implemented the 2 learning models? If so, what factors are inhibiting the implementation of the two models?

The internship program is part of the TF-based learning model that is very popular in schools. However, internships have not been proven to be the most optimal role in involving students in learning activities, and the impact has also not been optimal in shaping work readiness. For this reason, there needs to be built stronger synergy between schools and the business and industry so that the internship activities can play an optimal role in building work readiness.

\section{REFERENCES}

Arenas, Alberto. (2003). School-based enterprise and environmental sustainability. Journal of Vocational Education Research, 28 (2) 107-124.

Berita Resmi Statistik (2016). Dalam https://www.bps.go.id/pressrelease.html accessed 2 August 2016.

Berita Resmi Statistik (2018). Dalam https://www.bps.go.id/pressrelease.html accessed 2 August 2018.

Betz, N.E. (2004). Contribution of self-efficacy theory to carrier counseling: A personal perspective. Carrier Development Quarterly, 52, 340-353. 
Brady, R.P. (2010). Work Readiness Inventory (The booklet designed to accompany the Work Readiness Inventory). Indianapolis: JIST Publishing.

Caballero, C. L., Walker, A., Fuller-Tyszkiewicz. (2011). The Work Readiness Scale (WRS): Developing a measure to assess Work Readiness in college graduates. Journal of Teaching and Learning for Graduate Employability, 2(2) 41-54.

Clark, L. \& Winch, C. (2007). Vocational education international approach, development and system. New York: Routledge.

Cooper, S., Bottomley, C. \& Gordon, J. (2009) An experiential learning approach to entrepreneurship education: a British initiative. In: Manimala, M. J., Mitra, J. and Singh, V. (eds.) Enterprise Support Systems: An International Perspective. Sage Publications India: New Delhi.

Damarjati, Taufik. (2017). Teaching Factory in Indonesia. $3^{\text {rd }}$ High Officials Meeting on SEA-TVET 23-25 May 2017 Kuala Lumpur Malaysia.

European Centre for the Development of Vocational Training (Cedefop). (2011). The Benefits of Vocational Education and Training. Luxemburg: Publications Office of The European union.

Ferdinand, Augusty. (2002). Structural Equation Modeling dalam Penelitian Manajemen. Semarang: BP UNDIP.

Ferrandez Berrueco, Reina Maria; Kekale, Tauno; Devins, David. (2016). A framework for work-based learning: basic pillars and the interactions between them. Journal of Higher Eduation Skills and Work-Based Learning, 6(1) 35-54.

Gardner, H., Csikszentmihalyi, M., \& Damon, W. (2001). Good Work. New York: Basic Books.

Gardner, H. (2007). Responsibility at Work. San Fransisco:Jossey-Bass.

Haase, H.\& Lautenschlager, A. (2011). The "teachability dilemma" of entrepreneurship. International Entrepreneurship and Management Journal, 7. 55-70.

Hanafi, I. (2012). Re-orientasi ketrampilan kerja lulusan Pendidikan Kejuruan. Jurnal Pendidikan Vokasi, 2(1) 107-116.

Hasan, M. Z. (1995). Analisis Faktor. Makalah. Disampaikan pada lokakarya statistik dan analisis data penelitian. Malang: Lembaga Penelitian IKIP Malang.

Howard, A. (2004). Cooperative education and internships at the threshold of the twenty first century. In: P.L. Linn; A. howard \& E. Miller. Handbook for research in cooperative education and internships (pp.3-10). Mahwah NJ: Lawrence Erlbaum

Kasinath, H.M. (2013). Service learning: concept, theory and practice. International Journal of Education and Psychological Research, 2(2) 1-7.

Khurniawan, Ari Wibowo dan Haryani, Tri (Eds). (2016). Grand desain pengembangan teaching factory dan technopark di SMK. Jakarta: Direktorat Pembinaan Sekolah 
Menengah Kejuruan. Direktorat Jenderal Pendidikan Dasar dan Menengah Kementerian Pendidikan dan Kebudayaan.

McHug, P.P. (2017). The impact of compensation, supervision and work design on internship efficacy: implications for educators, employers, and prospective interns. Journal of Education and Work, 30(4) 367-382.

Moerwismadhi. (2009). Teaching factory suatu pendekatan dalam pendidikan vokasi yang memberikan pengalaman ke arah pengembangan technopreneurship. Makalah: Disampaikan pada seminar nasional technopreneurship learning for teaching factory tanggal 15 Agustus 2009 di Malang Jawa Timur.

Moorhouse, A., \& Caltabiano, M.L. (2007). Resilience and unemployment: Exploring risk and protective influences for the outcome variables of depression and assertive job searching. Journal of Employment Counseling. 44, 115-125.

Mulyatiningsih, Endang; Soegiyono; Purwanti, Sutriyati. (2014). Materi Pembekalan Pengembangan Edupreneurship Sekolah Menengah Kejuruan. Yogyakarta: Universitas Negeri Yogyakarta.

Parker, P. (2008). Promoting Employability at "Flat" World. Journal of Employment Counseling. 45, 2-13.

Porath, C.L. \& Bateman, C.S. (2006). Self-regulation: From goal orientation to job performance. Journal of Applied Psychology, 91, 185-192.

Prianto, A. (2013). Berbagai variabel yang mempengaruhi kesiapan bekerja para pencari kerja. Jurnal Manajemen Usahawan Indonesia, 42(3) 219-247.

Reynold, S.J. \& Ceranic, C.L. (2007). The effect of moral judgment and moral identity on moral behavior: An empirical examination of the moral individual. Journal of Applied Psychology. 92. 1610-1624.

Ruskyte, Dziuljeta \& Navickas, Vytas. (2017). Efficiency of teaching and learning methods for development of learner Entrepreneurship. Pedagogika/Pedagogy, 126(2) 168-184.

Sasmito, A.P., Kustono, D., \& Patmanthara, S. (2015). Kesiapan memasuki dunia usaha/dunia industri (DUDI) siswa paket keahlian rekayasa perangkat lunak di SMK. Jurnal Teknologi Kejuruan, 38(91): 2540.

Scheaffer, R.L.; Mendehall III, W.; Ott, R.L.; \& Gerow, K. (2012). Elementary Survey Sampling $\left(7^{\text {th }} E d\right)$. Boston, MA USA: Brooks/Cole, Cengage Learning.

Siswanto, Ibnu.2015. Teaching factory SMK Program Keahlian Otomotif. Prosiding Seminar Nasional Pendidikan Teknik Otomotif UMP tanggal 23 Mei 2015.

The European Union. (2012). Building Entrepreneurial Mindsets and Skills. https://publications.europa.eu/en/publication-detail/-/publication/0b119b3e-e072-42e3b3c5-a2746d386933 accessed 2 June 2019. 
Triatmoko. (2009). The ATMI Story, Rainbow of Excellence. Surakarta: Atmi Press

Wagner, J. O. 2006. Work readiness skills. Youth work Information Briefs. From: www.learningworkconnection.org. Accessed 12 January 2013. 